\title{
Sense-making of autonomy and control: Comparing school leaders in public and independent schools in a Swedish case
}

\author{
Daniel Nordholm ${ }^{1}$ (D) Anders Arnqvist ${ }^{1} \cdot$ Elisabet Nihlfors $^{1}$
}

Accepted: 2 June 2021 / Published online: 21 June 2021

(c) The Author(s) 2021

\begin{abstract}
This article analyses how school leaders depict their autonomy and how they make sense of the relationship between autonomy and control. Attention is drawn to three leadership focuses: the pedagogical direction of the school, decision-making over the internal organisation, and school improvement work. The article integrates survey data on Swedish school leaders $(n=1286)$. In addition, two theoretical categories were applied in the qualitative data analysis to explore how school leaders and local education authorities and its independent counterpart make sense of the relationship between autonomy and control: technical sense-making (TSM) and critical reflective learning. The findings showed that school leaders, both in public and independent schools, experienced a rather high degree of autonomy within the three focuses. The findings also indicated that school leaders in independent schools experienced a higher degree of autonomy regarding the pedagogical direction of the school and school improvement work. However, the effect sizes were low, indicating that the results must be considered with caution. The qualitative data analysis, in turn, revealed an overall emphasis on TSM among school leaders both in public and independent schools, reducing the possibilities for a novel and vibrant leadership. Based on these results, the article concludes that autonomy could constitute an important prerequisite for school leadership, but making sense of the relationship between autonomy and control stands out as even more important for successful school improvement.
\end{abstract}

Keywords Autonomy · Control · Decentralisation · Sense-making $\cdot$ Leadership · School system improvement $\cdot$ Sweden

Daniel Nordholm

daniel.nordholm@edu.uu.se

1 Faculty of Education, Uppsala University, Von Kraemers Allé 1, Box 2136, Uppsala, Sweden 


\section{Introduction}

In the last few decades, the concept of autonomy has attained increased attention in research on school improvement and school leadership. Comparable to efforts found in research on teacher autonomy and how this concept could contribute to educational change (e.g. Hattie, 2011; Sahlberg, 2011), researchers have approached the concept of school leaders' autonomy with different starting points. For instance, some studies have revealed a positive correlation between leadership autonomy, strategic decision-making and student performance (e.g. Fuchs \& Wössman, 2004), and between increased autonomy and curricular changes that improve students' results (Cladwell \& Spinks, 2013). A correlation between increased autonomy on a personal management level and literacy skills was also demonstrated in the work of Maslowski et al., (2007). However, it is emphasised that this correlation disappears when differences between schools' student composition are taken into account; therefore, Maslowski et al., (2007) stressed the importance of problematising the relationship between leadership autonomy and student learning further.

In doing so, Ko et al. (2016) argued that school autonomy and accountability are important dimensions of school leadership, but these elements are not enough for effective school improvement. It is argued that autonomy must be combined with profound leadership, comprehensive continuous professional development and a positive, collaborative school climate. In reviewing the current body of research, Cheng et al. (2016) also argued that traditional research on school autonomy is lacking. It is, for instance, claimed that too little attention has been paid to cultural autonomy and internal structural autonomy at individual and group levels, as well as to conceptual links between school autonomy and learning outcomes. Thus, Cheng et al. (2016) argued that internal autonomy could be equally important as external autonomy for school success.

Without overlooking these former paths, this article takes a somewhat different point of departure by relating to the work of Cribb and Gewritz, (2007), unpacking the concepts of autonomy and control in education (elaborated in further detail below). One argument put forward underlines the importance of moving beyond a normative presumption that autonomy should always be understood as something positive and control as negative, and instead looking into the complexity that surrounds these concepts. Cribb and Gewritz, (2007) also asserted that "underlying such approach is a view of autonomy/control as both "always in process and ubiquitous" and the concepts 'are constantly being made and remade, and negotiated and renegotiated in all of our daily interactions' (p. 205). Thus, negotiating and creating meaning of this relationship and adapting leadership to the local setting becomes an important and ongoing task for school leaders (cf. Hallinger, 2011).

Accordingly, this article does not intend to make an explicit contribution as to whether increased or decreased autonomy among school leaders leads to higher student results. Rather, the article aims to examine how Swedish school leaders depict their degree of autonomy and how they create meaning of the relationship 
between autonomy and control by addressing three areas of focus in school leaders' work, namely: the pedagogical direction of the school, decision-making over the internal organisation, and school improvement work. We believe there are strong arguments to centre these focuses. Regarding the first focus, the pedagogical direction of the unit, international as well as Swedish research, has for a long time showed the importance of a determined leadership, with an emphasis on the quality of teaching in addition to clear goals and shared values (see e.g. Hord, 2004; Johansson, 2016; Leithwood \& Montgomery, 1982). To empower such leadership, principals must also be given the mandate and prerequisites to actually lead the pedagogical direction of their units (author). Regarding school leaders' decision-making over the internal organisation, there is, here as well, a long tradition of research both internationally and in Sweden showing that school leaders' internal organisation becomes essential, both for students' and teachers' learning (see e.g. Schmuck \& Runkel, 1994; Ekholm, 1989; Fullan, 2001; Jones $\&$ Harris, 2014). It is important to note here that the current Education Act (2010: 800) also stipulates that Swedish principals have the mandate and task to organise their internal organisations. With regard to the third focus, school improvement, there is compelling research on the importance of school leadership for sustainable school improvement and educational change (see e.g. Townsend, 2007; Reynolds, 2005; Liljenberg, 2015). To this end, school leaders need a sufficient degree of autonomy, enabling them to adapt their leadership to the local context (cf. Hallinger, 2011).

Against this backdrop, the Swedish case (also described further below) stands out as very relevant. For this article, Sweden is often portrayed as a striking example of decentralisation and marketisation and a system in which public and independent $^{1}$ schools together form a school market from preschool to adult education (Allen, 2010; Lundahl, 2002a, 2002b; Rönnberg, 2015). However, up until now, we have had limited knowledge on the similarities and differences between school leaders in public and independent schools, for instance, when it comes to how they depict their degree of autonomy and how they create meaning of the relationship between autonomy and control in this decentralised system.

In a school system, such as the Swedish one, school leaders have to create meaning in dialogues with other educational professionals in the local municipality. One level that has proven to be of great importance in this regard is the central municipal level and how it interacts with school leaders in the local schools. For instance, from former research, we know that Local Education Authorities (LEAs) ${ }^{2}$ can have a key function in educational reforms and school improvements (see e.g. Anderson, et al., 2012; Campbell \& Murillo, 2005; Chapman \& Hadfield, 2010). Having stated this,

\footnotetext{
1 The term independent schools comprises a range of school organisers, i.e. from large school companies to small cooperatives. The schools are financed through a state voucher system and do not charge any fees.

2 The term LEA in Sweden generally refers to locally elected politicians and school administrators at the central municipal level. Regarding independent schools, there is a wide range of owner structures, ranging from a company board to a local board at the individual school level led by parents.
} 
there are also strong arguments for focusing on the relationship between school leaders and LEAs in local meaning-making.

The article analyses both quantitative and qualitative data attained from a survey on Swedish school leaders completed in January 2019 (subsequently detailed). Linked to the aim and the three focuses of this paper, some questions addressed the pedagogical direction of the school, decision-making over the internal organisation, and improvement work. The aim of the article is to analyse how Swedish school leaders depict their autonomy and how they negotiate and make sense of the relationship between autonomy and control. The following research questions directed the analytical work:

(1) How do Swedish school leaders depict their degree of autonomy in the areas of the pedagogical direction of the school, decision- making over the internal organisation, and improvement work?

(2) What similarities and differences exist between school leaders in public and independent schools and their sense-making of autonomy and control?

The article is structured as follows: First, the Swedish case is described. Then, the theoretical point of departure is outlined. Empirical material and methods are then introduced. In the following results presentation, quantitative and qualitative data are analysed in an integrated format. The result section is structured by the three autonomy focuses of certain importance for this article, namely: the pedagogical direction of the unit, decision-making over the internal organisation, and improvement work. The article ends with a discussion and implications for future research.

\section{Introducing the Swedish case}

From a historical perspective, an increasing number of school systems around the world have gradually become more decentralised and marked-adopted (e.g. Gewirtz \& Ball, 2000; Hargreaves \& Shirley, 2009; OECD, 2015; Pont et al., 2008). In this regard, the Swedish school system is often described as a striking example and sometimes even as a "pilot project" (Blossing et al., 2014; Seashore Louis, 2013). During the 1990s, the local municipalities in Sweden were given increased responsibility as Local Education Authorities (LEAs), becoming more directly responsible and accountable for their schools in 1991. Thus, LEAs and local school principals were responsible for issues related to school leadership and school improvement, as opposed to the former system in which they received detailed instructions from the government and its agencies (Lundahl, 2002a, 2002b). In connection with this shift, parents could now exercise their right to choose a school for their children other than the local school. Another market change in 1992, to improve school quality in Sweden, led to the start of a school system for independent school organisers. They, together with public schools, from this point onwards, form a school market in Sweden.

The Swedish case and the transformation, which in many ways started in the 1990s, is noteworthy from several perspectives. For instance, researchers have 
reasoned that the market orientation in Sweden led to a shift regarding the view on education, "from public good" to "private good" (Englund, 1994; Rönnberg, 2011). Former works have also argued that policy discourses in the early 1990s holding ideas on "bildung" and democratic values were displaced by an emphasis on goal attainment and a strengthened national control system (Bergh, 2015). Research have also claimed that Sweden's education policy moved from a political and ideological standpoint to a more one-sided focus on goal attainment and a narrower image of what quality in education is and should be (Arneback \& Bergh, 2010; Segerholm, 2009).

However, the challenges for school leaders and LEAs of navigating within and capitalising on the local freedom became evident over time (Swedish National Audit Office, 2004, 2011). Thus, a number of re-centralisation and re-regulation programmes have been launched and implemented since the early 2000s. The founding of the Swedish Schools Inspectorate in 2008, which regularly inspects and controls public and private school actors, has gradually led to increasing opportunities for injunctions, and imposition of fines, which are important examples of this "juridification" and re-centralisation process (Novak, 2018; Rönnberg, 2011, 2012). Recent research has also indicated that Swedish school leaders tend to support these re-centralisation reforms in favour of the "strong state" (author). In addition, school leaders also express doubts regarding market solution in the school system and request more regulation, for instance, to limit the possibilities to make a profit from education. However, it is important to recognise that the decentralised and marked-adopted school system appears to stand strong from an international perspective. In support of such a claim, the "Swedish School Commission" (SOU, 2017: 35) suggested in 2017 that further steps should be taken to prevent school segregation and to limit the possibilities for school companies to make a profit. Despite similar recommendation from the Organisation for Economic Cooperation and Development (OECD, 2015), these proposals have had a modest impact and so far, there has been no political consensus in line with the Commission's recommendations.

Against this background and the international developments described above, indicating that other countries are moving in a similar direction as Sweden, it becomes relevant to study school leaders' understandings of the relationship between autonomy and control in such a system. This focus could add important details on the relationship between educational policy, school leadership and how educational change actually takes place in a decentralised and market-adapted school system. In this respect, it is relevant to draw a dividing line between school leaders in public and independent schools to explore the similarities and differences that prevail in such a system. This stands out as important, both from a national and international perspective.

\section{Theoretical perspective}

Previous research showed that the phenomenon of autonomy is multifaceted and that the concept can have a shifting nature in a school context (e.g. Ingersoll, 1996; Wermke and Forsberg, 2017). In this regard, in elaborating on the relationship between 
autonomy and control, Cribb and Gewirtz (2007) proposed that one approach to understand the concept is to pay certain attention to the "loci" of autonomy and control. Regarding teacher autonomy, Cribb and Gewirtz argued the loci is the teacher (individual or group level), but it can also have a number of sources at the local, regional and national level-e.g. school management, peers, parents, local school governance, steering documents, and so forth. This article takes an analogous point of departure, claiming that the duality between autonomy and control becomes equally important for school leaders. In addition, the loci of autonomy and control builds an important framework also for school leaders' autonomy and sense-making activities in different settings.

Regarding the concept of sense-making, school leaders in different contexts have to navigate, negotiate and "make sense" to handle the situations that arise in their leadership. Thus, researchers have argued that we must widen our understanding of how school leaders create meaning of novel, complex situations (see e.g. Spillane \& Anderson, 2014; Spillane \& Lee, 2014). One way to explore how members of organisations make sense and create meaning is provided in the work of Weick, (1995). In the context of an organisation, sense-making is a rather pragmatic process in which members of organisations, individually and collectively, reduce complexities to make sense and create meaning (Weick, 1995). The procedure involves a continuous process of interaction between information interpretation and a coherent knowledge structure. The sense-making procedure is also closely linked to the type or nature of the organisation. According to Weick, (1976), school organisations are more "loosely coupled" than other organisations. Consequently, less fixed forms of coordination and significant room for self-determination affect school leaders and teachers as they try to "make sense" of their organisational life. Thus, this also becomes an important starting point for school leaders in making sense of the relationship between autonomy and control.

The work of Weick has, in turn, been further developed and become more sophisticated. For instance, $\mathrm{Ng}$ and Tan, (2009) investigated how sense-making affects the nature of learning, using a community of practice as an example. They argued that sense-making should be understood as a learning process that is largely technical in nature and often limited to immediate practical matters. Thus, there is a broader dividing line between pure and technical sense-making (hereinafter TSM) and critical, reflective learning (hereinafter CRL). According to $\mathrm{Ng}$ and Tan, (2009, p. 39), 'Sense-making looks for a plausible interpretation rather than an accurate one'. In their conclusion, $\mathrm{Ng}$ and Tan suggest that communities of practice should move from TSM towards CRL, using tools that allow teachers to explore and create new knowledge.

Nevertheless, it is relevant to consider some criticisms of Weick and his colleagues' work. In reviewing and mapping out critique of the sense-making perspective, Sandberg and Tsoukas, (2015) showed that one important strand of the criticism holds that the notion of "process" remains relatively vague in the current body of research. Another topic of criticism, also deepened in the work of Weber and Glynn, (2006), maintains that the larger context in which sense-making occurs is often overlooked and therefore, researchers should consider the larger institutional setting to a larger extent. These former areas for critique also appear relevant for the 
work of $\mathrm{Ng}$ and Tan, (2009). However, regarding the first area of critique, i.e. vagueness of the concept of process, the analysis below strives to detect the type of sensemaking processes that may take place and not to identify the specific elements of these processes. Moreover, the institutional setting is well-presented and taken into consideration in the current paper. Arguably, the municipal and national context is integrated, not only in the analytical work but also in the discussion and conclusion sections.

Accordingly, Ng and Tan's work on sense-making proved to be a valuable lens in analysing qualitative survey data on how school leaders negotiate and make sense of the relationship between autonomy and control. This appears as a process of negotiation in which school leaders must create meaning together with LEAs or its independent counterpart. Arguably, it is essential to distinguish what characterises these negotiations of autonomy and control, and how different loci impinge on and frame the sense-making activities.

\section{Materials and methods}

Regarding the survey, email addresses to principals were attained from the Swedish National Agency for Education. According to official statistics (see the Swedish National Agency for Education, 2019), there are currently about 3,600 principals in Sweden working in full-time services. In the current study, temporarily appointed or hired-in principals were excluded, as they have limited possibilities to answer detailed questions on the three identity dimensions. Deputy principals were also excluded because, in a Swedish context, these principals do not have an overall responsibility from a leadership perspective. Principals with responsibility for both preschools and schools were however included as a group. Taking these aspects into consideration, the survey was distributed to approximately 3000 principals. After sending the initial email, it became obvious that the email addresses were not entirely updated, and some work was undertaken to find "missing" principals. New emails were sent to these principals. Two reminders were sent out to all principals.

The final sample of principals $(n=1,286)$ comprises 249 out of 290 local municipalities. This resulted in a response rate of 42.6 per cent. The sample comprised principals working in public and independent schools. In this sample, the percentage of principals working in public and independent schools is 83.3 per cent and 17.7 per cent, respectively. According to official statistics from the Swedish National Agency for Education, (2019), the figures for all comprehensive schools in Sweden are 81 per cent principals in public school and 19 per cent principals in independent schools. Compared to the statistics from National Agency for Education, the sample also represents variation in age, size of school and number of years in professions, which is in line with the population of principals in comprehensive schools.

Regarding the non-response analysis, some possible factors can be highlighted. One difficulty already mentioned was the struggle to obtain updated email addresses from the National Agency for Education. Another closely related challenge was that since Swedish principals tend to change jobs more often than their European colleagues (OECD, 2016), their positions are often vacant and quite a lot of principals 
are replaced with a temporary principal. One additional factor was that some emails got stuck in municipal spam filters; therefore, all reminders were sent directly to the schools. Thirteen of the principals that responded were also excluded because of missing data or they did not meet the criterion of being head of a preschool, primary or secondary school.

\section{The quantitative data analysis}

The questionnaire consisted of 42 questions. However, only questions on school leaders' backgrounds and those addressing aspects of autonomy and control were used in this analysis. The first part of the questionnaire included questions about the following variables.

- School authorities (independent or public)

- Type of school (preschool, primary or secondary)

- Type of municipality

- Gender

- Age

- Time as principal

In the second part, the school leaders were asked to estimate their degree of autonomy as heads of the school. The school leaders were asked to answer the questions by indicating on a scale ranging from 1 to 6 the extent to which they agreed with the statements, formulated as follows in the questionnaire:

How do you rate the degree of autonomy as a school leader from the following aspects?

- Decisions regarding the direction of the pedagogical work at my unit

- Decisions regarding the school/preschool's internal organisation

- Decisions regarding school improvement work

Data were analysed with assistance of software for quantitative data analysis (SPSS) by comparing distributions of ratings for the questions concerning autonomy and control for principals in public and independent schools. The analyses were conducted by computing Chi2 measures and investigating differences between observed and expected values for the two categorical variables, items in the questionnaire and type of school authority. Stockemer (2019) suggests using Chi2 test when analysing categorical data. Special attention was drawn to the questions addressing the pedagogical direction of the school, decision-making over the internal organisation, and improvement work.

This showed that some aspects of the operationalisation process and the analytical work could be highlighted. To start with, it is worth noting that school leaders' autonomy can include many dimensions and angles. As noted in the introduction section, this article primarily focuses on autonomy in the relationship between school leaders, the LEAs and the Superintendent. Against this 


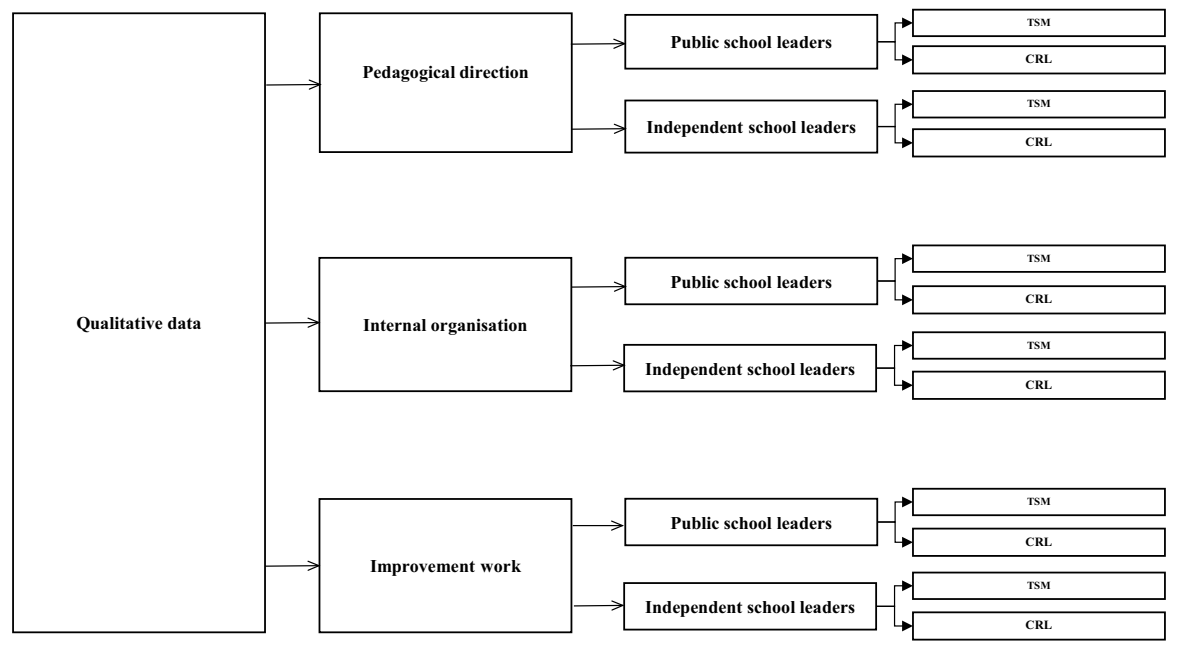

Fig. 1 Analysis scheme

background, questions were selected based on school leaders' (perceived) autonomy primary in relation to the Superintendent and the LEAs. Thus, the survey did not ask questions on other areas of autonomy, e.g. linked to parents, teachers, the Agency for Education, national school inspectorate, and so forth. It is also worth noting that no questions have been removed in the analytical work, e.g. because they did not result in any measurable effects.

\section{The qualitative data analysis}

Inspired by Miles et al. (2014) work on how to display qualitative data analysis, an analysis scheme was also developed to structure the analytical work (also see Fig. 1). Data from free text answers were imported and analysed with the assistance of software for qualitative data analysis (NVivo 12). Four specific questions were imported for further NVivo-coding:

1. What expectations do you experience from your immediate superior?

2. Is there something in your school/preschool and in your municipality that affects your leadership very much?

3. Give one example where you have been prepared to "stretch" the rules or formal procedures to perform a task in line with your values.

4. Give one example where you experienced low/high degree of autonomy in deciding on: (a) the pedagogical direction of your school, (b) decision-making over your internal organisation, and (c) improvement work. 
Free text answers from the four questions were integrated into the analytical work on the same criteria as the quantitative scale questions, i.e. they primarily addressed school leaders' (perceived) autonomy and sense-making activities in relation to the Superintendent and the LEAs. Accordingly, other questions were not taken into consideration, for instance, on autonomy in relation to other actors such as parents, staff, the political board, because they did not address the primary focus of the article.

In the first step of the analysis, data were coded into the three focuses of autonomy and control (the pedagogical direction of the school, decision-making over the internal organisation, and improvement work). Second, public and independent school leaders were separated from each other to distinguish relevant patterns of responses between the groups. Third, the two groups' sense-making of the three focuses of autonomy and control were divided into theoretically driven codes (see e.g. Gibbs, 2007), consistent with the two types of sense-making identified in the work of $\mathrm{Ng}$ and Tan, (2009), namely "TSM" and "CRL". In analysing locus of autonomy and control (e.g. the school leader, LEAs and the Superintendent), extracts of TSM labelled the relationship between autonomy and control as rather fixed but sometimes also vague. More specifically, following the work of $\mathrm{Ng}$ and Tan, (2009), sense-making activities in this category were identified as rather nonnegotiable, limited, inflexible, non-explorative and less dialogical, demonstrating a rather powerless, constrained but sometimes also deserted school leader. Thus, the criteria of TSM show a rather technical sense-making process, in which school leaders voiced limited prospects for shared learning and/or impacting the prevailing relationship between the two concepts, specifically in the relationship to the LEA and the Superintendent.

Regarding CRL, on the other hand, these extracts labelled the relationship between autonomy and control as more dynamic, reciprocal and evolving-i.e. as a learning process. Based on the work of $\mathrm{Ng}$ and Tan, (2009), in this category school leaders described their sense-making activities, more in terms of a dialogue between them and the LEAs/Superintendent in which they have gained trust and a mandate to act and explore their autonomy. Thus, in contrast to TSM, in this category, autonomy is described as a more negotiable and extensible phenomenon. Moreover, in this category, sense-making school leaders also voiced their support and feedback in the sense-making dialogues from the central municipal level or the independent counterpart.

Finally, it is worth emphasising that each anonymised school leader is unique, i.e. they are only referred to once in the presentation of the results.

\section{Results}

The results section is structured as follows. The presentation follows the three focuses for studying the relationship between autonomy and control. Each part starts with results from the quantitative analyses. The results of the qualitative analyses are then integrated within each section. 
Table 1 Distribution of principals' rated degree of autonomy regarding the schools' pedagogical direction divided by school authority

\begin{tabular}{llll}
\hline $\begin{array}{l}\text { Degree of } \\
\text { autonomy* }\end{array}$ & Public schools & $\begin{array}{l}\text { Independent } \\
\text { school }\end{array}$ & Total \\
\hline 1 & 7 & 3 & 10 \\
& $.7 \%$ & $1.3 \%$ & $.8 \%$ \\
2 & 13 & 4 & 17 \\
& $1.2 \%$ & $1.8 \%$ & $1.3 \%$ \\
3 & 40 & 13 & 53 \\
& $3.8 \%$ & $5.8 \%$ & $4.2 \%$ \\
4 & 127 & 22 & 149 \\
& $12.2 \%$ & $9.8 \%$ & $11.7 \%$ \\
5 & 388 & 62 & 450 \\
& $37.2 \%$ & $27.6 \%$ & $35.50 \%$ \\
6 & 468 & 121 & 590 \\
& $44.9 \%$ & $53.8 \%$ & $46.5 \%$ \\
\hline
\end{tabular}

$*$ Rating scale $1=$ low degree of autonomy and $6=$ high degree of autonomy

\section{The pedagogical direction of the school}

Table 1 shows the distribution of ratings divided by type of school authority. It can be concluded by the ratings that principals rated their possibility to decide on the pedagogical direction of the unit as rather high. Only 6 per cent of the principals rated their autonomy as low by indicating on the scale rating 1 to 3 .

A Chi-square test of autonomy was performed to examine the relationship between ratings on the question regarding decisions on pedagogical direction of the school and type of school authority. The relationship between these two categorical variables was significant, $\mathrm{X}^{2}(2, N=1,286)=11.94, \mathrm{p}<0.001$. This indicates that principals in public schools rated their autonomy as being lower than principals in independent schools. However, measure of the effect size of this finding, Cramers V, was low (0.10).

Based on these results, it becomes relevant to integrate the qualitative data analyses to obtain a more detailed image. Analogous to the quantitative analysis, the overall image indicated some support regarding differences between school leaders in public and independent schools regarding the degree of experienced autonomy. However, when it comes to the character of the sense-making activities, the analyses instead detected important similarities.

Going into details, a cluster of school leaders in public schools described that it is their Superintendent and their LEAs that decide the prioritised goals for the school year and that these goals in turn direct the educational activities, demonstrating sense-making processes closer to TSM. In some of these cases, school leaders also claimed that their Superintendents and LEAs were not familiar with "school issues", which made it difficult for them to have a professional dialogue. Moreover, school leaders in public schools argued that goals identified in the 
local units were few and had limited impact. This quote from a school leader in a public school exemplifies these descriptions:

I receive more obligations from the central (municipal) administration and more often, which has resulted in my acting space being decreased significantly, and that decisions have been made at central municipal level, where I have not been able to have an impact.

Regarding school leaders in independent schools, the analysis detected an emphasis on TSM here as well, but it is important to note that the sense-making negotiations had a somewhat different character. Analogous to the public school leaders, these school leaders described that they had limited possibilities for negotiation and to influence the direction of their work. Regarding expectations, they exemplified that they are obligated to run the school in the pedagogical direction determined by the specific board, as described here by a school leader:

That the business should generate profit. I should work with sales and student recruitment. I should create cost-effective solutions and at the same time, as far as possible, not make it difficult for the pupils to achieve the teaching goals.

As the quotation indicates, the sense-making process, here categorised as TSM, has reduced the school leader's understanding of the pedagogical direction of the school to generate profit and raise students' results. The quote gives, however, no clues as to whether the school leader wants or can influence the previous negotiations in a different direction.

In this first part of the analysis, there were additional examples of TSM, albeit of a different nature. More precisely, both public and independent school leaders argued that there were no ongoing negotiations or dialogues concerning the pedagogical direction of their schools, on prioritised goals, on the potential need for support, on empowerment and inspiration, and so forth. Accordingly, these school leaders depicted rather elusive sense-making processes, wherein they had to create their own meaning in a more technical learning process in which complexity must be reduced-not least because certain issues have a rather complex nature and require a conversation between different professionals and levels of the school system. A school leader in a public school expressed this in terms of expectations from the LEAs:

I am expected to do everything on my own that concerns my own school... that I just let the development continue as usual, even though there are many big issues for which I need support from the Superintendent or the LEA. Although I have communicated that I want more clarity and consensus on several issues, it will not be so. I have no expectations.

However, the analysis also identified examples of sense-making processes closer to CRL, particularly among school leaders in independent schools. In these examples, the negotiations between school leaders and the LEAs or its independent counterpart had more of an ongoing and non-fixed character, including issues 
on autonomy and control. School leaders, for example, described that they were expected to "take responsibility for their units", that "others had a lot of confidence in them" and they were supposed to "work independently and solve problems" that arose, but at the same time they felt "great support" and that their superiors "put a lot of trust in them". A school leader in an independent school expressed the expectations of the school board regarding the pedagogical direction of the school as follows:

To follow the work description from KFO, our employer organisation. I have expectations from the others on the board and the association. These expectations are linked to the job description as well as the Education Act and the nationwide curriculum.

Another school leader described similar expectations in this way:

To ensure that the business works well and that we follow the (nationwide) curriculum and other control documents, that I have a dialogue between the pedagogical activities (in the school) and the board so they are knowledgeable about what is happening. That I participate and create a workplace where everybody thrives and feels involved.

The two latter quotes hold elements of a sense-making process that is more categorised by CRL. Regarding the first quote, the school leader described that there is a job description that could serve as a common starting point in the negotiations between her/him, the employer organisation and the school board. Such starting points, arguably, increase the prospects for understanding roles and responsibilities, and also for the relationship between autonomy and control. Concerning the second quote, the school leader described her/his role as a sense-maker, both up and down the system, enabling a shared understanding between different levels. In contrast to sense-making processes characterised by TSM above, there is also a wider expectation regarding the school leader's work and the values that should direct the pedagogical leadership. More precisely, it is not only profit and high goal fulfilment that are prioritised, which require a more in-depth sense-making process, where goals and leadership dimensions are discussed and understood in a qualitatively different way.

Summing up this first section, the analyses gave some support for the conclusion that school leaders in independent schools experience a higher degree of autonomy regarding the pedagogical direction of the school. However, it is important to emphasise that sense-making activities, generally, had the character of TSM. Nonetheless, school leaders in both public and independent schools labelled that sense-making can also occur in qualitatively different ways, generating a deeper understanding of autonomy and control between school leaders, LEAs or its independent counterpart.

\section{Decision-making over the internal organisation}

Table 2 reflects the distribution of ratings divided by type of school authority. It can be concluded by the ratings that school leaders rated their possibility to decide on the internal organisation as rather high. Nearly 34 per cent of the school 
Table 2 Distribution of school leaders' rated degree of autonomy on decisions over the internal organisation divided by school authority

\begin{tabular}{llll}
\hline $\begin{array}{l}\text { Degree of } \\
\text { autonomy }\end{array}$ & Public school & $\begin{array}{l}\text { Independent } \\
\text { school }\end{array}$ & Total \\
\hline 1 & 6 & 4 & 10 \\
& $0.6 \%$ & $1.8 \%$ & $0.8 \%$ \\
2 & 28 & 3 & 31 \\
& $2.7 \%$ & $1.3 \%$ & $2.4 \%$ \\
3 & 42 & 13 & 55 \\
& $4.0 \%$ & $5.8 \%$ & $4.3 \%$ \\
4 & 110 & 33 & 143 \\
& $10.5 \%$ & $14.7 \%$ & $11.3 \%$ \\
5 & 373 & 61 & 434 \\
& $35.7 \%$ & $27.2 \%$ & $34.2 \%$ \\
6 & 485 & 110 & 595 \\
& $46.5 \%$ & $49.1 \%$ & $46.9 \%$ \\
\hline
\end{tabular}

$*$ Rating scale $1=$ low degree of autonomy and $6=$ high degree of autonomy

leaders rated their autonomy to a very high degree. Only 7 per cent of the school leaders rated their autonomy as low by indicating on a scale of 1 to 3 .

The analytical work also centred ratings on decisions over the internal organisation and type of school authority. A Chi-square test of autonomy was performed to examine the relationship between ratings on the question regarding decisions over the internal organisation and type of school authority. The relationship between these two categorical variables was $\mathrm{X}^{2}(2, N=1,286)=13.18, p=0.02$. This indicates that principals in public schools rated their autonomy over their internal organisation as being lower than the ratings made by principals in independent schools. However, measures of the effect size of this finding, Cramers V, were low (0.18).

The qualitative data analysis in turn showed several similarities with the first part of the analysis. In describing the local sense-making activities, school leaders in both public and independent schools described the negations as a process that is often characterised by TSM. A common opinion was that LEAs or its independent counterpart had clear beliefs on how the internal organisation should look, both at an overall level, but also in certain details. This, for example, included roles and positions in the organisation, issues relating to wage setting and employment, but also specific schedule issues. Several school leaders also highlighted that they in fact had the formal mandate to form their internal organisation according to the current Education Act and nationwide curriculum; but in reality, it looked rather different. A school leader in a public school explained:

I have the Education Act to relate to when it comes to decisions on the internal organisation. At the same time, I get no understanding from the LEAs who do not listen or want to relate to this. On paper, I have the right to decide, but the conditions... mean that it is not complied with. 
The quotation above demonstrates a sense-making process in which school leaders' autonomy and acting space are perceived as firmly limited. In addition, it is worth noting that the school leader relates to the formulations of the Education Act, stipulating the mandate to decide and form their internal organisations. Still, technical sense-making appears to prevail, leaving less room for negotiation and shared sense-making.

However, in this second part of the analysis, some differences between school leaders in public and independent schools were also detected. More precisely, even though sense-making activities of the internal organisation, generally, was characterised by TSM school leaders, school leaders at independent schools experienced a clarity regarding how they could (or should) design their internal organisation and what boundaries were present. School leaders in public schools, instead, used expressions such as "blurred", "uncertain", "fuzzy" and "tricky" more frequently as they described the framework and local negotiations. A school leader in a public school clarified:

(I have a) controlling manager who wants me as a school leader to be at the workplace all the time. I experience lack of encouragement and personal development before a complex assignment as a school leader. I have a very diffuse work description that should contain everything.

Despite an emphasis on TSM, there were several examples also in this part that were closer to CRL. In these cases, school leaders described the sense-making negotiations with LEAs or the independent counterpart as "responsive", "supportive" and "trustful". School leaders pointed out, for example, that they had been given the mandate to design their internal organisation and appoint leadership roles to teachers, which "has empowered a distributed leadership". In addition, they emphasised shared expectations to build "sustainable organisations" to "create an attractive school within a certain budget". Having the approval to create "collaborative teams based on the local needs" was also highlighted as another important aspect of forming the internal organisation, enabling the management team, the development group(s) and student healthcare to jointly drive the school's work forward.

Summing up this second part, the analyses showed comparable results to the quantitative analyses, i.e. no clear differences between school leaders in public and independent schools. In addition, and comparable to the first section was that sense-making activities between school leaders and their superiors, generally, were depicted in terms of TSM. School leaders described their autonomy as rather restricted or that the negotiations are "completed", giving them less opportunity to influence the form and content of improvement work. However, it is important to note in this regard that independent school leaders expressed that they had more clarity regarding how they could (or should) design their internal organisation compared to public school leaders who described the relationship between autonomy and control in terms such as fuzzy and vague. Regarding the sense-making activities characterised by CRL, school leaders described the dialogues and negotiations with LEAs or the independent counterpart as supportive, mutual and trustworthy. These processes were also described more in terms of an ongoing negotiation and an exploratory approach, where learning and development are in a constant process. 
Table 3 Distribution of school leaders' rated degree of autonomy on school improvement divided by school authority

\begin{tabular}{llll}
\hline $\begin{array}{l}\text { Degree of } \\
\text { autonomy }\end{array}$ & Public school & $\begin{array}{l}\text { Independent } \\
\text { school }\end{array}$ & Total \\
\hline 1 & 6 & 1 & 7 \\
& $0.6 \%$ & $0.4 \%$ & $0.6 \%$ \\
2 & 19 & 5 & 24 \\
& $1.8 \%$ & $2.2 \%$ & $1.9 \%$ \\
3 & 62 & 12 & 74 \\
& $5.9 \%$ & $5.4 \%$ & $5.8 \%$ \\
4 & 177 & 29 & 206 \\
& $17.0 \%$ & $12.9 \%$ & $16.2 \%$ \\
5 & 458 & 59 & 517 \\
& $43.9 \%$ & $26.3 \%$ & $40.8 \%$ \\
6 & 322 & 118 & 440 \\
& $30.8 \%$ & $52.7 \%$ & $34.7 \%$ \\
\hline
\end{tabular}

*Rating scale $1=$ low degree of autonomy and $6=$ high degree of autonomy

\section{School improvement}

Table 3 shows the distributions of ratings divided by type of school authority. It can be concluded by the ratings that school leaders rated their possibility to decide on school improvement as rather high. Nearly 34 per cent of the school leaders rated their autonomy to a very high degree. Only 8 per cent of the school leaders rated their autonomy as being low by indicating on a scale of 1 to 3 .

A Chi-square test of autonomy was performed to examine the relationship between ratings on the question regarding decisions over the internal organisation and type of school authority. The relationship between these two categorical variables was $\mathrm{X}^{2}(2, N=1,286)=41.39, p<0.001$. This indicates that principals in public schools rated their autonomy lower than ratings made by principals in independent schools. However, measures of the effect size of this finding, Cramers $\mathrm{V}$, were low (0.11).

Going into details, the overall image becomes somewhat more complex. The analysis indicated that the negotiations and sense-making processes, generally, are characterised more by TSM than CRL, among school leaders both in public and independent schools, and no clear differences were therefore detected. School leaders, for example, described that their ability to influence and determine the direction and goals of improvement work is rather limited because goals are often determined by the LEA or the independent school owner. One public school leader reasoned that the prevailing structure in the municipality turns them into "implementers" in a "corporate group think". Another school leader in a public school described:

Low degree of autonomy applies to all school improvement work because the work is prevented by the prevailing structure... In the role of a school 
leader, autonomy is completely limited to school improvement work because of the structure decided by the Superintendent.

The quote indicates a rather narrow and technical learning process, in which both LEAs and school leaders create meaning by reducing the complexity that exists within and between different levels in the system. These school leaders also drew the conclusion that they can hardly decide anything at all regarding school improvement issues.

In the other extreme, the analysis detected answers that imply a similar sensemaking process of the relationship between autonomy and control. These school leaders, however, describe a process in which they are required to create meaning of school improvement issues on their own without negotiations with LEAs and its independent counterpart. School leaders in public schools, for example, argued that LEAs are not interested in school improvement issues as long as the school's budget is in balance. Similar descriptions emerge from school leaders of independent schools. Answering the question on what expectations the school's board have regarding improvement work, a school leader explained:

None at all! Because there are parents on the school board; they do not have sufficient knowledge. As long as I present good results, they have no expectations beyond the ones I have on myself and my school activity.

One argument to categorise the last quote as TSM holds that school leaders are forced to create their own meaning in school improvement issues without further dialogues or support from colleagues at the school level above them. Thus, understanding and tackling the complexities that these issues contain on their own reduces the opportunities for an in-depth and ongoing process in which learning takes place in negotiation and dialogue.

However, in this section as well, the analysis identified examples more characterised by CRL, although they were relatively few. Somewhat in contrast with the quantitative analysis, it was mainly school leaders in public schools who explained how dialogues and negotiations can also reinforce a shared and deepened sense-making process. For example, they explained that "the local municipality formulates wider goals at the central municipal level from which school leaders can choose" and then works in close dialogue with the LEA. In other cases, school leaders expressed that they were given much responsibility and autonomy by their Superintendent, but also that "they received help and support if needed to operate the improvement work". According to these school leaders, LEAs and school leaders explore the relationship between autonomy and control jointly. A public school leader described the expectations and negotiations that exist regarding improvement work:

There are high expectations (from LEAs) that I will perform a good job (regarding school improvement). There is a trust that I can perform my duties. (But also) that I signal to my superiors if I cannot operate/handle the (improvement) work.

To summarise this last section, one overall finding maintains that sense-making of autonomy and control within improvement work was mainly characterised by 
TSM. More precisely, school leaders in public and independent schools expressed that they are either controlled and restricted on these issues, or that they are given an extensive acting space without further dialogues, both with the LEA or with the direction of the independent counterpart. However, examples that were more characterised by CRL were also found, mostly among school leaders in public schools.

\section{Discussion}

The quantitative analysis showed that school leaders, both in public and independent schools, experienced a rather high degree of autonomy within the three leadership focuses. At the same time, the analysis also indicated that school leaders in independent schools experienced a slightly higher degree of autonomy regarding the pedagogical direction of the school and school improvement work. The qualitative data analysis partly confirmed these results regarding the pedagogical direction of the unit, but not regarding school improvement. Another overall result, mostly detected within the second focus, i.e. decision-making over the internal organisation, was that school leaders in independent schools experienced more clarity regarding their assignment which possibly, helped them to identify potential autonomy more easily compared to public school leaders. However, it is worth emphasising that the differences between the two groups were quite small and that there was an overall emphasis on TSM. School leaders, for instance, experienced that LEAs or the independent counterparts often went into detail on issues related to the pedagogical direction of the school, the internal organisation, and school improvement. Another type of sense-making process characterised by TSM, mostly described by school leaders in independent schools, indicated the opposite relationship, that is, school leaders were entirely left alone within the three areas of focus. In these cases, creating meaning without support and encouragement from the LEAs ought to reduce the opportunities for an exploratory and open learning process, that is, CRL. A third type of sense-making impinged by TSM, as expressed by independent school leaders, reduced their assignment to generating profit, finding cost-effective solutions and increasing students' results.

The analysis, however, found important examples within the three areas in which school leaders' descriptions indicated sense-making activities as being more characterised by CRL. In these examples, school leaders described the dialogues and negotiations with LEAs or the independent counterpart as supportive, mutual and trustworthy. School leaders also expressed that they are given considerable responsibility and mandate but unlike the examples characterised by TSM, they described that there was an ongoing dialogue and a learning process in which they were also offered feedback and support if necessary.

Accordingly, some overall results are important to highlight. Initially, it is relevant to note that the perceived degree of autonomy is quite high among school leaders in both public and independent schools, which however is partly contradicted by the results of the qualitative analysis. Another important result to note is that the differences between the two groups are small, although school leaders in independent schools experienced a higher degree of autonomy within two of the three focus 
areas of school leadership. However, these distinct patterns of responses became more difficult to identify in the qualitative analysis, except for the pedagogical direction of the school, where some support was found for the results of the quantitative analyses.

In light of these results, there are strong arguments to reason that what becomes essential from a school improvement perspective is how sense-making of autonomy and control are negotiated and not the degree of autonomy in itself. For instance, the qualitative analyses identified that high degree of autonomy does not automatically generate CRLs because school leaders, both in public and independent schools, can be fairly alone in their sense-making activities without constructive negotiations with LEAs or the independent counterpart. The fact that there is a clear emphasis on TSM, also in areas where school leaders identify a clear mandate and support in the current policy documents, raises further questions. For instance, what happens in a system where school leaders often experience that they receive detailed and nonnegotiable directives on which pedagogical direction their units should take, on how their internal organisation should look, and in school improvement issues? Also, what happens to school leader's creativity, engagement and professionalism in such a system? In this regard, it is also relevant to reflect upon the limited prospects to work with school improvement issues rooted in the local school context, i.e. a wellknown factor for successful leadership (cf. Hallinger, 2011).

Against this backdrop, it might be argued that it is problematic that sense-making activities and negotiations between the different levels were mostly characterised by TSM. As noted in the introduction, LEAs and other middle-level intermediaries can play an important role in successful school improvement (cf. Anderson et al., 2012; Campbell \& Murillo, 2005; Chapman \& Hadfield, 2010). In the current case, LEAs and their independent counterpart seldom undertook this function or role; consequently, a large part of the potential for leadership learning did not occur. This finding demonstrates a need for expanded dialogues characterised by CRL between school leaders and LEAs or their independent counterpart in Sweden and other countries in order to strengthen deepened understandings of the relationship between autonomy and control and the complexity that surrounds these concepts. This might be particularly important in a decentralised and market-adopted school system, which also becomes relevant from an international perspective, given the background that education systems around the globe have gradually tended to move in the Swedish direction (cf. Allen, 2010; Hargreaves \& Shirley, 2009; OECD, 2015).

\section{Conclusion}

This article has analysed how school leaders depict their autonomy and how they make sense of the relationship between autonomy and control. Attention was drawn to three leadership focuses: the pedagogical direction of the school, decision-making over the internal organisation, and school improvement work. The article integrates survey data on Swedish school leaders $(n=1286)$. In addition, two theoretical categories were applied in the qualitative data analysis to explore how school leaders and 
local education authorities (LEAs) and their independent counterpart make sense of the relationship between autonomy and control: technical sense-making (TSM) and critical reflective learning (CRL). The findings indicated that school leaders, both in public and independent schools, experienced a rather high degree of autonomy. The findings indicate that school leaders in independent schools experienced a slightly higher degree of autonomy regarding the pedagogical direction of the school and school improvement work. However, the low effect sizes indicated that the results must be viewed with caution. The distribution of scores were skewed, with tendencies of ceiling effects. Thus, in future studies, the operationalisation of autonomy must be developed to achieve a normal distribution of scores. The qualitative data analysis, however, revealed an overall emphasis on TSM reducing the possibilities for a novel and vibrant leadership in both public and independent schools. Based on these results, the article concludes that autonomy could constitute an important prerequisite for school leadership, but making sense of the relationship between autonomy and control is arguably even more important for successful school improvement.

Regarding further research, there is a need for more in-depth studies, for instance, on why some school leaders, LEAs or their independent counterparts manage to establish sense-making dialogues closer to CRL than TSM. Hence, we need to learn more about how these municipalities and independent school owners developed these dialogues, what conditions have been given, as well as mandates, roles and positions that contribute to a successful school improvement. Another alternative could be to design one or several research projects in collaboration with local professionals and together explore improvement needs and potential ways forward, for instance, as an action research project. This, in fact, could constitute one example of supporting structures requested above.

Lastly, the data in this article are rich, which opens up for further analysis using more advance statistical methods. However, this article mainly focused on comparing the qualitative and quantitative analysis. Thus, in forthcoming works, more advance statistical methods are applied, and measures of background factors are used to control for differences in the sample.

Funding Open access funding provided by Uppsala University.

Open Access This article is licensed under a Creative Commons Attribution 4.0 International License, which permits use, sharing, adaptation, distribution and reproduction in any medium or format, as long as you give appropriate credit to the original author(s) and the source, provide a link to the Creative Commons licence, and indicate if changes were made. The images or other third party material in this article are included in the article's Creative Commons licence, unless indicated otherwise in a credit line to the material. If material is not included in the article's Creative Commons licence and your intended use is not permitted by statutory regulation or exceeds the permitted use, you will need to obtain permission directly from the copyright holder. To view a copy of this licence, visit http://creativecommons.org/licen ses/by/4.0/. 


\section{References}

Allen, R. (2010). Replicating Swedish 'free school' reforms in England. Research in Public Policy, 10, 4-8.

Anderson, S., Mascall, B., Stiegelbauer, S., \& Park, J. (2012). No one way: Differentiating school district leadership and support for school improvement. Journal of Educational Change, 13(4), 403-430. https://doi.org/10.1007/s10833-012-9189-y

Arneback, E., \& A. Bergh. 2010. Den paketerade valfriheten - Om Framtidsvägen för den svenska gymnasieskolan. [The Pre-packaged Freedom of Choice - On the Future of Swedish Upper Secondary School.] Nordic Studies in Education, 30(2), 117-131

Bergh, A. (2015). Local quality work in an age of accountability-between autonomy and control. Journal of Education Policy, 30(4), 590-607. https://doi.org/10.1080/02680939.2015.1017612

Blossing, U., Imsen, G., \& Moos, L. (2014). Nordic schools in a time of change. In U. Blossing, G. Imsen, \& L. Moos (Eds.), The Nordic Educational Model: 'A School for all' Encounters Neo-Liberal Policy. Policy Implications of Research in Education 1 (pp. 1-14). Dordrecht: Springer.

Campbell, C., \& Murillo, F. J. (2005). Big change question. Do local central authorities (LCAs) make a difference in school reform? Journal of Educational Change, 6(1), 77-86. https://doi.org/10. 1007/s10833-004-7785-1

Chapman, C., \& Hadfield, M. (2010). Supporting the middle tier to engage with school-based networks: Change strategies for influencing and cohering. Journal of Educational Change, 11(3), 221-240. https://doi.org/10.1007/s10833-009-9125-y

Cheng, Y. C., Ko, J., \& Tai Hoi Lee, T. (2016). School autonomy, leadership and learning: a reconceptualization. International Journal of Educational Management, 30(2), 177-196. https://doi. org/10.1108/IJEM-08-2015-0108

Cladwell, B. J., \& Spinks, J. M. (2013). The self-transforming school (1st ed.). Routledge.

Cribb, A., \& Gewirtz, S. (2007). Unpacking autonomy and control in education: Some conceptual and normative groundwork for a comparative analysis. European Educational Research Journal, 6(3), 203-213. https://doi.org/10.2304/eerj.2007.6.3.203

Ekholm, M. (1989). Att organisera en skola [To organize a school]. In L. Svedberg \& M. Zaar (Eds). Skolans själ [The school's soul]. Stockholm: Utbildningsförlaget

Englund, T. (1994). Education as a citizenship right-A concept in transition: Sweden related to other western democracies and political philosophy. Journal of Curriculum Studies, 26(4), 383-399. https://doi.org/10.1080/0022027940260403

Fuchs, T., \& Wössman, L. (2004). What accounts for international differences in student performance? A re-examination using PISA-data. Working paper No 1236, Munich: University of Munchen.

Fullan, M. (2001). Leading in a culture of change. Jossey-Bass.

Gewirtz, S., \& Ball, S. (2000). From 'Welfarism' to 'New Managerialism': Shifting discourses of principalship in the education marketplace. Discourse: Studies in the Cultural Politics of Education, 21(3), 253-268. https://doi.org/10.1080/713661162

Gibbs, G. R. (2007). Analyzing qualitative data. Sage Publications.

Hargreaves, A., \& Shirley, D. (2009). The fourth way: The inspiring future of educational change. Corwin Press.

Hattie, J. (2011). Visible learning for teachers. Maximizing impact on learning. Routledge.

Hallinger, P. (2011). Leadership for learning: Lessons from 40 years of empirical research. Journal of Educational Administration, 49(2), 125-142. https://doi.org/10.1108/09578231111116699

Hord, S. M. (2004). Learning Together, Leading Together. Changing Schools Through Professional Learning Communities. Teachers' College Press: New York

Ingersoll, R. M. (1996). Teachers' decision-making power and school conflict. Sociology of Education, 69(2), 159-176.

Johansson, O. (2016). Successful school leadership: International perspectives. Bloomsbury Academic.

Jones, M., \& Harris, A. (2014). Principals leading successful organisational change: Building social capital through disciplined professional collaboration. Journal of Organisational Change Management, 27(3), 473-475. 
Ko, J., Cheng, Y. C., \& Tai Hoi Lee, T. (2016). The development of school autonomy and accountability in Hong Kong: Multiple changes in governance, work, curriculum, and learning. International Journal of Educational Management, 30(7), 1207-1230. https://doi.org/10.1108/IJEM-10-2015-0145

Leithwood, K. A., \& Montgomery, D. (1982). The role of the elementary school principal in program improvement. Review of Educational Research, 52(3), 309-339.

Liljenberg, M. (2015). Distributing leadership to establish developing and learning school organisations in the Swedish context. Educational Management, Administration \& Leadership, 43(1), 152-170.

Lundahl, L. (2002a). From centralisation to decentralisation: Governance of education in Sweden. European Educational Research Journal, 1(4), 625-636. https://doi.org/10.2304/eerj.2002.1.4.2

Lundahl, L. (2002b). Sweden: Decentralization, deregulation, quasi-markets-and then what? Journal of Education Policy, 17(6), 687-697. https://doi.org/10.1080/0268093022000032328

Maslowski, R., Scheerens, J., \& Luyten, H. (2007). The effect of school autonomy and internal decentralization in students' reading literary. School Effectiveness and School Improvement, 18(3), 303-334. https://doi.org/10.1080/09243450601147502

Miles, M. B., Huberman, A., \& Saldaña, J. (2014). Qualitative data analysis: A methods sourcebook (3rd ed.). Sage Publications.

Ng, P. T., \& Tan, C. (2009). Community of practice for teachers: Sensemaking or critical reflective learning? Reflective Practice, 10(1), 37-44. https://doi.org/10.1080/14623940802652730

Nordholm, D., \& Andersson, K. (2019). Newly appointed principals' descriptions of a decentralized and marked adopted school system: An institutional logics perspective. Educational Management, Administration \& Leadership, 47(4), 572-589. https://doi.org/10.1177/1741143217751075.

Novak, J. (2018). Juridification of educational spheres: The case of Swedish school inspection. Acta Universitatis Upsaliensis.

OECD. (2015). Improving schools in Sweden: An OECD perspective. OECD Publishing.

OECD. (2016). Principalship for Learning. Insights form TALIS 2013. OECD Publishing. Retrieved from http://www.keepeek.com/Digital-Asset-Management/oecd/education/ school-leadership-forlearning_9789264258341-en\#.V_YgrefJ700.

Pont, B., Nusche, D., \& Moorman, H. (2008). Improving school leadership: Policy and practice. Directorate for education, education and training policy division. Paris: OECD.

Reynolds, D. (Ed.). (2005). The practice and theory of school improvement. Dordrecht: Springer.

Rönnberg, L. (2011). Exploring the intersection of marketization and central state control through Swedish national school inspection. Education Inquiry, 2(4), 689-707. https://doi.org/10.3402/edui.v2i4. 22007

Rönnberg, L. (2012). Reinstating national school inspections in Sweden-The return of the state. Nordic Studies in Education, 2, 70-80.

Rönnberg, L. (2015). Marketization on export: Representations of the Swedish free school model in English media. European Educational Research Journal, 14(6), 549-565. https://doi.org/10.1177/14749 04115610782

Sahlberg, P. (2011). Finnish lessons. What can the world learn from educational change in Finland? Teachers College Press.

Sandberg, J., \& Tsoukas, H. (2015). Making sense of the sensemaking perspective: Its constituents, limitations, and opportunities for further development. Journal of Organizational Behaviour, 36(1), $6-32$.

Schmuck, R. A., \& Runkel, P. J. (1994). The handbook of organization development in schools and colleges (4th ed.). Waveland Press.

Seashore Louis, K. (2013). Districts, local education, authorities, and the context of policy analysis. Journal of Educational Administration, 51(4), 550-555. https://doi.org/10.1108/09578231311325695

Segerholm, C. (2009). "We are Doing Well on QAE": The Case of Sweden. Journal of Education Policy, 24(2), 195-209. https://doi.org/10.1080/02680930902734103

Skollag (2010: 800) [Education Act 2010: 800]. Stockholm: Utbildningsdepartementet

Spillane, J. P., \& Anderson, L. (2014). The architecture of anticipation and novices' emerging understandings of the principal position: Occupational sense making at the intersection of individual, organization, and institution. Teachers' College Record, 116(7). Colombia University.

Spillane, J. P., \& Lee, L. C. (2014). Novice school principals' sense of ultimate responsibility: Problems of practice in transitioning to the principal's office. Educational Administration Quarterly, 50(3), 431-465. https://doi.org/10.1177/0013161X13505290

Stockemer, D. (2019). Quantitative methods for the social sciences. Springer. 
Swedish Government Official Reports (SOU) 2017: 35. Samling för skolan - Nationell strategi för kunskap och likvärdighet [Consensus for the school - National strategy for knowledge and equivalence].

Swedish National Agency for Education (2019). Pedagogisk personal i skola och vuxenutbildning läsåret 2018/2019 [Pedagogical staff in schools and adult education in the school year of 2018/2019]. Retrieved from: www.skolverket.se/download/18.6bfaca41169863e6a65d8b3/1553968305611/ pdf4050.pdf.

Swedish National Audit Office (2004). Betyg med lika värde? - en granskning av statens insatser [Marks with equal standards? A review on the governmental efforts]. Stockholm, Sweden: The Parliament's Printing Works.

Swedish National Audit Office (2011). Lika betyg, lika kunskap? En uppföljning av statens styrning mot en likvärdig betygsättning $i$ grundskolan [Equal marks, equal knowledge? A follow-up study of governmental governing towards equal grading in elementary school]. Stockholm, Sweden: The Parliament's Printing Works.

Townsend, T. (Ed.). (2007). International handbook of school effectiveness and improvement: Review, reflection and reframing. Springer.

Weber, K., \& Glynn, M. A. (2006). Making sense with institutions: Context, thought and action in Karl Weick's Theory. Organization Studies, 27(11), 1639-1660.

Weick, K. E. (1976). Educational organizations as loosely coupled systems. Administrative Science Quarterly, 21(1), 1-19.

Weick, K. E. (1995). Sensemaking in organizations. Sage Publications.

Wermke, W., \& Forsberg, E. (2017). The changing nature of autonomy. Transformations of the late Swedish teaching profession. Scandinavian Journal of Educational Research, 61(2), 155-168.

Publisher's Note Springer Nature remains neutral with regard to jurisdictional claims in published maps and institutional affiliations. 